\title{
Notes on the Distribution of the Genus Oreochromis in the East Mediterranean Region of Turkey
}

\author{
Pinar ARSLAN ${ }^{*}$, Deniz INNAL ${ }^{2}$, Saniye Cevher OZEREN ${ }^{3}$ \\ ${ }^{1}$ Çankırı Karatekin University, Department of Biology, Çankırı, Turkey \\ ${ }^{2}$ Mehmet Akif Ersoy University, Department of Biology, Burdur, Turkey \\ ${ }^{3}$ Ankara University, Department of Biology, Ankara, Turkey \\ ORCID ID: Pınar ARSLAN: https:/ / orcid.org/0000-0001-5910-2835; Deniz INNAL: https://orcid.org/0000-0002-1686-0959; Saniye Cevher \\ OZEREN: https:// orcid.org/0000-0002-8509-0548
}

\begin{abstract}
Received: 11.11 .2020
Accepted: 30.01 .2021

Published online: 31.03 .2021

Issue published: 30.06 .2021

Abstract: Tilapias are freshwater species which are the common name of three genera of cichlids, Oreochromis, Sarotherodon, and Coptodon. Many of the species belonged to these genera have been used for aquaculture products. Although their main native distribution areas are tropical and subtropical regions, they have spread to other areas due to their high invasive characteristics. This study was aimed to investigate the distribution of genus Oreochromis in the East Mediterranean Region of Turkey. The study was conducted at 18 stations located in Adana and Mersin from 2014 to 2017. The introduction of the species in these systems was mainly recorded weed control, transfers of fisherman, and escape from aquaculture facilities. However, the distribution of genus Oreochromis in Turkey and their effects on the aquatic ecosystems are unknown. The results showed that the species of genus Oreochromis were easily adapted the different conditions such as various flow rates, salinity, and temperature.
\end{abstract}

Keywords: Tilapia, Oreochromis, freshwater systems, native, invasive.

\section{Oreochromis Cinsinin Türkiye'nin Doğu Akdeniz Bölgesi'ndeki Dağılımına İlişkin Notlar}

\begin{abstract}
Öz: Tilapialar, üç cins çiklit olan Oreochromis, Sarotherodon ve Coptodon'un ortak adı olan tatlı su türleridir. Bu cinslere ait türlerin çoğu, su ürünleri yetiştiriciliğinde kullanılır. Ana doğal dağılım alanları tropikal ve subtropikal bölgeler olmasına rağmen, yüksek istilacı özelliklerinden dolayı diğer bölgelere yayılmışlardır. Bu çalışma Türkiye'nin Doğu Akdeniz Bölgesi'nde Oreochromis cinsinin dağılımını araştırmayı amaçlamıştır. Çalışma, 2014-2017 yılları arasında Adana ve Mersin'de bulunan 18 istasyonda gerçekleştirildi. Bu sistemlere türlerin girişi, ağırlıklı olarak yabancı ot kontrolü, balıkçı transferleri ve su ürünleri tesislerinden kaçış olarak kaydedildi. Fakat Oreochromis cinsinin Türkiye'deki dağılımı ve sucul ekosistemler üzerindeki etkisi halen bilinmemektedir. Sonuçlar, Oreochromis türlerinin çeşitli akış hızlarına, tuzluğa ve sıcaklığa sahip farklı koşullara adapte olduğunu göstermektedir.
\end{abstract}

Anahtar kelimeler: Tilapia, Oreochromis, tatlı su sistemleri, doğal, istilacı.

\section{Introduction}

The family Cichlidae, within the order Perciformes, is one of the most abundant families of fish. They are tropical freshwater species and their native habitats are mainly located tropical and subtropical regions of America and Africa, as well as Madagascar, India, and Sri Lanka (Salzburger \& Meyer, 2004; Maan \& Sefc, 2013). However, they can also be found as non-native species such as Florida in America (Schofield et al., 2014), in North, South and Central America (Cassemiro et al., 2018), in Thailand (Nico et al., 2007), in Germany (Lukas et al., 2017), in Portugal (Carecho et al., 2018), and in Russia (Zworykin \& Pashkov, 2010). The family is represented by 250 genera, including Tilapia (Froese \& Pauly, 2019).

Tilapia is the most well-known member of this family as a common name of the three genera that are Oreochromis, Sarotherodon, and Coptodon (Mohamed \& Al-wan, 2020), each includes many species such as Nile tilapia Oreochromis niloticus, Magadi tilapia Sarotherodon alcalicus grahami, and Guinean tilapia Coptodon guineensis. Among tilapias, the genus Oreochromis is represented with 89 species. They inhabit in mainly freshwater as well as estuaries as nonnative species in almost 100 countries and as native species in Africa. They possess a big slender body shape with small eyes and a terminal mouth (Froese \& Pauly, 2019).

According to the Food and Agriculture Organization of the United Nations (FAO, 2018), this genus has an important possession of aquaculture. The farming of tilapias and other cichlids is currently increasing, having reached 1.6 million tonnes in 2016. For instance, Nile tilapia Oreochromis niloticus was the most produced aquaculture followed by carps, at $8 \%$ of total production in 2016. In addition, the other species of Oreochromis spp. was also produced at $2 \%$ of the total in 2016. The most produced culture of Oreochromis spp. is currently established on hybrids between $O$. niloticus, O. aureus, and O. mossambicus species (D'Amato et al., 2007). They are not only used as food sources but also used for their skin as the leather of making clothing, shoes, belts, and other accessories due to being a large fish. They have also been used as a disease control vector such as for malaria and Zika (FAO, 2018). Besides their use in aquaculture, leather textile, and vector, they are popular in the aquarium trade due to their various 
coloration and behavior habits (Welcomme, 1988).

In Turkey, the aquaculture of tilapia production has changed over the years. According to the Turkish Statistical Institute (2020), tilapia was produced 32 tons in 2014, 12 tons in 2015, 58 tons in 2016, 8 tons in 2017, and 12 tons in 2018. However, some of the species escaped and released into the other freshwater systems (Dikel \& Celik, 1998; Celik \& Gökce, 2003; Gökce et al., 2003). O. aureus and O. niloticus were introduced and now are found as non-native species in open systems including reservoirs, rivers, and closed systems. Their introduction in the freshwater systems resulted in different aims (Innal, 2012). It was reported that O. niloticus found in Asi River (Gürlek, 2004), Köyceğiz Lake (Yılmaz, 2009), Damsa Dam Lake (Mert \& Çiçek, 2010), Sakarya River basin (Emiroğlu, 2011), Pınarbaşı Creek (Burdur) (Innal \& Sungur, 2009), and O. aureus found in Seyhan Dam Lake (Gökce et al., 2003). However, the knowledge of the distribution and effects of Oreochromis spp. in the natural freshwaters of Turkey is scarce. Therefore, in this study, the existence of this species in Adana and Mersin region of Turkey and their possible introduction to these systems have been reported.

\section{Material and Methods}

The study was carried out from November 2014 to June 2017 in the Eastern Mediterranean Region (Adana and Mersin) in accordance with the internationally accepted principles for laboratory animal use and care that followed the Local Ethics Committee of Experimental Animals (Decision Number: 93773921-18, Date: 20 February 2013). A total of 18 sites (Ceyhan River, Bahçe Channel, Kulak Creek, Çakırören Creek, Karagöçer Creek, Köprügözü Channel, Terliksiz DSI pump channel, Seyhan River, Baharlı Creek, Berdan River, Atalar Channel, Keloğlu Channel, Kapızlı Creek, Göksu River, Paradeniz Lagoon and Channel, Akgöl Channel, Kurtuluş Village Channel, Arkum Channel), representing a variety of habitats (including river and creeks, irrigation canals, lagoonal canals), were repeatedly surveyed. Sampling sites with its locality and habitat description are given in Table 1. Sampling localities are given in the map below (Fig. 1).

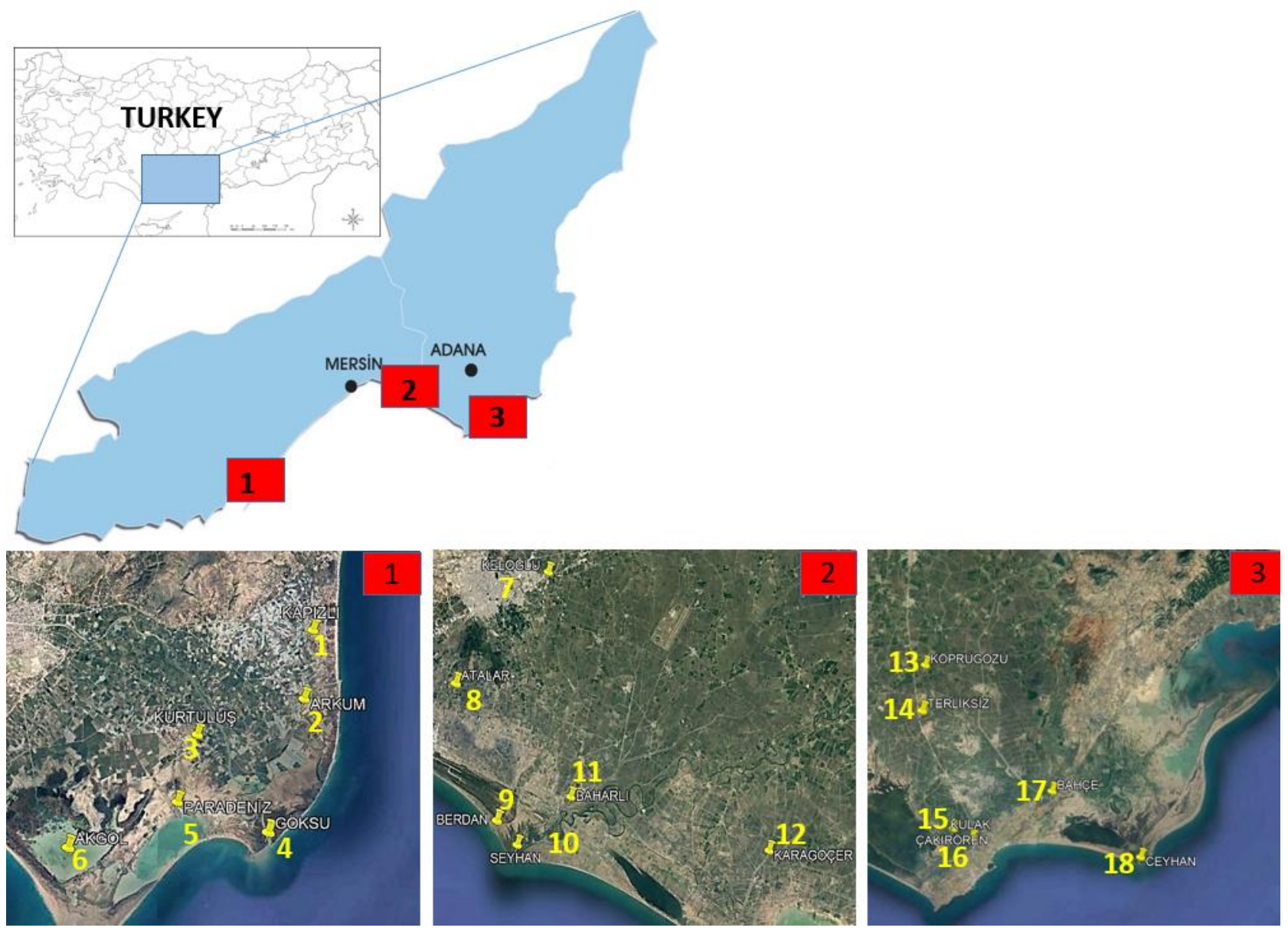

Figure 1. Map of Turkey showing sampling localities. Region 1. (1- Kapızlı Creek, 2- Arkum Channel, 3- Kurtuluş Village Channel, 4Göksu River, 5- Paradeniz Lagoon and Channel, 6- Akgöl Channel); Region 2. (7- Keloğlu Channel, 8- Atalar Channel, 9- Berdan River, 10- Seyhan River, 11- Baharlı Creek, 12- Karagöçer Creek); Region 3. (13- Köprügözü Channel, 14- Terliksiz DSI pump channel, 15- Kulak Creek, 16- Çakırören Creek, 17- Bahçe Channel, 18- Ceyhan River)

Oreochromis species of the systems were sampled using gill nets of various mesh sizes $(10,17,23$, and $30 \mathrm{~mm}$ bar lengths), cast nets, and fish traps. The fish were kept in $4 \%$ formaldehyde until they were brought to the Biology Laboratory of Burdur Mehmet Akif Ersoy University. Before the determination of the species, the fish in formaldehyde were kept in water for a day to remove the formaldehyde. Then, the fish were kept in $70 \%$ ethanol to be analyzed. Fish species were identified according to Kottelat and Freyhof (2007).

\section{Results}

Species of Oreochromis established in the sampling localities and their purpose for introduction are given in Table 2. 
Water channels in Göksu Wetland and Çukurova region are subject to many introductions and transfers of Oreochromis species for weed control and aquaculture purpose. Oreochromis species were detected in 18 systems in Mersin and Adana region. In the studied systems, nonindigenous Oreochromis species have been identified along

Table 1. Sampling sites with its locality and habitat description

\begin{tabular}{|c|c|c|c|c|c|}
\hline No & Locality & Region & Flow velocity & Latitude & Longitude \\
\hline 1 & Kapızlı Creek & Silifke-Mersin & Steady & $36^{\circ} 22^{\prime} 27.06^{\prime \prime} \mathrm{N}$ & $34^{\circ} 03^{\prime} 54.72^{\prime \prime} \mathrm{E}$ \\
\hline 2 & Arkum Channel & Silifke-Mersin & Steady & $36^{\circ} 20^{\prime} 55.02^{\prime \prime} \mathrm{N}$ & $34^{\circ} 03^{\prime} 41.42^{\prime \prime} \mathrm{E}$ \\
\hline 3 & Kurtuluş Village Channel & Silifke-Mersin & Steady & $36^{\circ} 20^{\prime} 05.77^{\prime \prime} \mathrm{N}$ & $34^{\circ} 00^{\prime} 45.18^{\prime \prime} \mathrm{E}$ \\
\hline 4 & Göksu River & Silifke-Mersin & Fast & $36^{\circ} 17^{\prime} 57.80^{\prime \prime} \mathrm{N}$ & $34^{\circ} 2^{\prime} 53.12^{\prime \prime} \mathrm{E}$ \\
\hline 5 & Paradeniz Lagoon and Channel & Silifke-Mersin & Steady & $\begin{array}{l}36^{\circ} 18^{\prime} 35.10^{\prime \prime} \mathrm{N} \\
36^{\circ} 18^{\prime} 27.51^{\prime \prime} \mathrm{N}\end{array}$ & $\begin{array}{l}34^{\circ} 00^{\prime} 13.55^{\prime \prime} \mathrm{E} \\
34^{\circ} 0^{\prime} 39.00^{\prime \prime} \mathrm{E}\end{array}$ \\
\hline 6 & Akgöl Channel & Silifke-Mersin & Steady & $36^{\circ} 19^{\prime} 50.65^{\prime \prime} \mathrm{N}$ & $33^{\circ} 56^{\prime} 14.74^{\prime \prime} \mathrm{E}$ \\
\hline 7 & Keloğlu Channel & Tarsus-Mersin & Steady & $36^{\circ} 55^{\prime} 33.16^{\prime \prime} \mathrm{N}$ & $34^{\circ} 56^{\prime} 35.15^{\prime \prime} \mathrm{E}$ \\
\hline 8 & Atalar Channel & Tarsus-Mersin & Steady & $36^{\circ} 50^{\prime} 50.15^{\prime \prime} \mathrm{N}$ & $34^{\circ} 51^{\prime} 13.66^{\prime \prime} \mathrm{E}$ \\
\hline 9 & Berdan River & Tarsus-Mersin & Moderate & $36^{\circ} 47^{\prime} 47.40^{\prime \prime} \mathrm{N}$ & $34^{\circ} 56^{\prime} 18.43^{\prime \prime} \mathrm{E}$ \\
\hline 10 & Seyhan River & Tarsus-Mersin & Fast & $36^{\circ} 43^{\prime} 50.61^{\prime \prime} \mathrm{N}$ & $34^{\circ} 54^{\prime} 45.74^{\prime \prime} \mathrm{E}$ \\
\hline 11 & Baharlı Creek & Tarsus-Mersin & Steady & $36^{\circ} 45^{\prime} 54.22^{\prime \prime} \mathrm{N}$ & $34^{\circ} 57^{\prime} 53.13^{\prime \prime} \mathrm{E}$ \\
\hline 12 & Karagöçer Creek & Karataş-Adana & Slow & $36^{\circ} 43^{\prime} 35.23^{\prime \prime} \mathrm{N}$ & $35^{\circ} 09^{\prime} 25.18^{\prime \prime} \mathrm{E}$ \\
\hline 13 & Köprügözü Channel & Karataş-Adana & Slow & $36^{\circ} 44^{\prime} 37.23^{\prime \prime} \mathrm{N}$ & $35^{\circ} 20^{\prime} 41.79^{\prime \prime} \mathrm{E}$ \\
\hline 14 & Terliksiz DSI pump channel & Karataş-Adana & Slow & $36^{\circ} 40^{\prime} 00.28^{\prime \prime} \mathrm{N}$ & $35^{\circ} 19^{\prime} 56.71^{\prime \prime} \mathrm{E}$ \\
\hline 15 & Kulak Creek & Karataş-Adana & Steady & $36^{\circ} 35^{\prime} 34.79^{\prime \prime} \mathrm{N}$ & $35^{\circ} 22^{\prime} 52.84^{\prime \prime} \mathrm{E}$ \\
\hline 16 & Çakırören Creek & Karataş-Adana & Slow & $36^{\circ} 36^{\prime} 08.90^{\prime \prime} \mathrm{N}$ & $35^{\circ} 21^{\prime} 44.36^{\prime \prime} \mathrm{E}$ \\
\hline 17 & Bahçe Channel & Karataş-Adana & Steady & $36^{\circ} 37^{\prime} 41.81^{\prime \prime} \mathrm{N}$ & $35^{\circ} 28^{\prime} 13.09^{\prime \prime} \mathrm{E}$ \\
\hline 18 & Ceyhan River & Karataş-Adana & Fast & $36^{\circ} 34^{\prime} 10.83^{\prime \prime} \mathrm{N}$ & $35^{\circ} 33^{\prime} 36.15^{\prime \prime} \mathrm{E}$ \\
\hline
\end{tabular}

Table 2. Species of Oreochromis established in the sampling localities and their purpose for introduction

\begin{tabular}{llll}
\hline No & Locality & Species & Purpose of introduction \\
\hline 1 & Kapılı Creek & Oreochromis sp. & Weed control \\
2 & Arkum Channel & Oreochromis sp. & Unknown \\
3 & Kurtuluş Village Channel & Oreochromis niloticus & Unknown \\
4 & Göksu River & Oreochromis niloticus & Unknown \\
5 & Paradeniz Lagoon and Channel & Oreochromis niloticus & Unknown \\
6 & Akgöl Channel & Oreochromis sp. & Unknown \\
7 & Keloğlu Channel & Oreochromis sp. & Weed control \\
8 & Atalar Channel & Oreochromis sp. & Weed control \\
9 & Berdan River & Oreochromis niloticus & Weed control and transfers of fisherman \\
10 & Seyhan River & Oreochromis niloticus & Escape from Aquaculture facilities \\
11 & Baharlı Creek & Oreochromis niloticus & Escape from Aquaculture facilities \\
12 & Karagöçer Creek & Oreochromis spp. & Weed control \\
13 & Köprügözü Channel & Oreochromis sp. & Weed control \\
14 & Terliksiz DSI pump channel & Oreochromis sp. & Weed control \\
15 & Kulak Creek & Oreochromis niloticus & Weed control and transfers of fisherman \\
16 & Çakı̈ron Creek & Oreochromis sp. & Weed control \\
17 & Bahçe Channel & Oreochromis niloticus & Weed control and transfers of fisherman \\
18 & Ceyhan River & Oreochromis niloticus & Escape from Aquaculture facilities \\
\hline
\end{tabular}

\section{Discussion}

Freshwater ecosystems possess rich biodiversity, an active role in water cycling, and an important source of food and water for human populations (Havel et al., 2015). They are invaded by non-native species via international shipping, aquaculture, ornamental fish training, biological control of diseases, new fisheries techniques, and inter-basin transfers (Tarkan et al., 2015). Although the biological invasions by non-native species may have positive effects on the native ecosystems such as aquaculture, ornamental and recreational purposes (Ewel et al., 1999), they cause adverse effects on native biota including extinctions of endemic and native species and even human health as carrying parasites (Ferrari \& Hoffman, 1992).

The first introduction of non-native tilapias is inferred to occur in Java (Indonesia) in the 1930s because of the aquarium releasing of Mozambique tilapia, O. mossambicus (Courtenay \& Williams, 1992). Fish began to be used as aquaculture products - in terms of being in the category of white meat such as chicken meat and being cheap compared to beef and pork in the 1970s. similar chicken meat and cheap economic prices comparing with beef and pork in the with native fish species Acanthobrama orontis (Berg, 1949), A. marmid (Heckel, 1843), Luciobarbus pectoralis (Heckel, 1843), Garra culiciphaga (Pellegrin, 1927), Cyprinus carpio (Linnaeus, 1758), Chondrostoma ceyhanensis (Küçük et al., 2017) and, members of Mugilids. 
Turkey has increased in recent years. Thirty non-native fish species were recorded in 2019, including Oreochromis aureus (Steindachner 1864) and O. niloticus (Linnaeus 1758) (Innal \& Sungur, 2019). Oreochromis spp. was first introduced in Turkey in the 1970s by transplanting into Lake Burdur but they were all dead due to temperature differences (Gürlek, 2004). Then, several tilapia species brought from Syria and introduced into Seyhan Dam Lake by General Directorate of State Hydraulic Works in 1976. Afterward, owing to scientific researches their counts were increased and transferred to several Fisheries Institutes and research facilities. In the meantime, they were introduced intentionally/ accidentally in the freshwater systems (Altun et al., 2006). They can easily adapt to the newly introduced environment, reproduce rapidly, and become invasive where they affect native species, especially endemic species. However, they distribute easily and rapidly through lentic and lotic ecosystems, human impact is the first reason to introduce the non-native species in the natural ecosystems (Tarkan, 2013). According to the General Directorate of State Hydraulic Works (2020), studies are continued to introduce with suitable fish species within the scope of aquaculture activities in reservoirs and dam lakes including commercial hunting, fish farming in net cages, aquaculture, amateur hunting, and development of other aquaculture models. Besides, some species are used for the biological control of diseases. It is stated that the first vaccination of Gambusia holbrooki in the freshwaters of Turkey as a precaution for the biological control of malaria against vector mosquitoes between 1920 and1929 (Walton et al., 2012). Even though Oreochromis mossambicus were used as a bioindicator organism in different types of studies including disease infection (Yilmaz et al., 2013; Gültepe et al., 2014; Yilmaz et al., 2014) in the universities of Turkey by making its culture, the species has not been recorded in open freshwater systems in Turkish.

Although the genus of Oreochromis distribution of Turkey has been studied, the effects of the species have not been known in these systems. However, there is some information about their effects on the other aquatic systems. Bittencourt et al. (2014) reported that the fish composition of the Amazonas River (Brazil) changed the invasion of $O$. niloticus. Although the other native cichlid species were in the river, in a short time O. niloticus was higher biomass than the others. Because of filter-feeding omnivorous species, Nile tilapia caused the changing of plankton biomass during and after an algal bloom in tropical lakes in the Rio Grande do Norte (Brazil) (Vasconcelos et al., 2018). The changes in the population of Nile tilapia and red-spotted sunfish (Lepomis miniatus) that live in the same environmental conditions were shown with the experimental design of the estuaries of the Gulf of Mexico. The red-spotted sunfish population decreased when there was a predator in the tank with both species. Thus, it was indicated that Nile tilapia was more competitive than the other species (Martin et al., 2010). According to Khan et al. (2011), the native fish species of Pakistan have been under threat due to the introduction of non-native species including $O$. niloticus, O. aureus, and O. mossambicus. Comparıng the feeding behavior of Nile tilapia with/without introducing another species (Nile perch, Lates niloticus) in Lake Nabugabo (Uganda) showed that herbivorous feeding was features of Nile tilapia without Nile perch (Bwanika et al., 2006).

The present study showed that freshwater systems in
Adana and Mersin are the convenient habitat for Oreochromis spp. Because they are easily adapted to the different environmental conditions, including salinity and temperature (Ford et al., 2019), they inhabit these systems where the morphological, chemical, and biological structures of 18 systems differ from each other, especially in Ceyhan, Seyhan, and Goksu River. They were detected in the systems where some endemic species were also detected. Their effects on these endemic species have not been known yet. During the field studies, it was observed that Oreochromis spp. found dense populations in Seyhan River and Baharli Creek. The introduction of the species in these stations was determined as weed control, transfers of fisherman, and escape from the aquaculture facilities. Therefore, we can specify the factors affecting the distribution of this genus as anthropogenic factors. Another anthropogenic factor was identified that this genus is used as a food source. People who lived in the villages around the stations caught Oreochromis spp. from the stations, especially from creeks. Due to the pollution of these systems, health problems may occur in the future for those who feed on these fish and in the aquatic ecosystem in which they are located.

\section{Conclusion}

As a consequence of this research, it is revelaed that Oreochromis spp. inhabits within the freshwaters in Adana and Mersin due to the resembling environmental conditions of their native habitats. Their feeding characteristics and high reproduction rate cause their predominant population there. Besides, there are many native fish species in the stations and the effects of Oreochromis spp. are still not clear. Further research should be done to figure out the effects of Oreochromis spp. on native and endemic fish species and sufficient control methods should be developed for this invading species.

Ethics committee approval: This study was performed in accordance with ethical standards of animal experiments. Legal research ethics committee approval permissions for the study were obtained from the Mehmet Akif Ersoy University, Animal Experiments Local Ethics Committee (No: 93773921-18).

Conflict of interest: The authors declares that there is no conflict of interest.

\section{References}

Altun, T., Tekelioğlu, N., \& Danaba, D. (2006). Tilapia culture and its problems in Turkey. Ege University Journal of Fisheries \& Aquatic Sciences, 23(3-4), 473-478.

Beryl, R., Jawahar, T., Roy, A., Singha, J., Boda, S., \& Kumar, P. (2019). Dietary influences of oxytetracycline on the growth and serum biomarkers of Oreochromis niloticus (L.). Ecotoxicology and Environmental Safety, 186, 109752. https://doi.org/10.1016/j.ecoenv.2019.109752

Benli, A.Ç.K., \& Özkul, A. (2010). Acute toxicity and histopathological effects of sublethal fenitrothion on Nile tilapia, Oreochromis niloticus. Pesticide Biochemistry and Physiology, 97(1), 32-35. https://doi.org/10.1016/j.pestbp.2009.12.001

Bittencourt, L.S., Silva, U.R.L., Silva, L.M.A., \& Traves-Dias, M. (2014) Impact of the invasion from Nile tilapia on natives Cichlidae species in tributary of Amazonas River, Brazil. Biota Amazonia, 4(3), 88-94. https://doi.org/10.18561/2179-5746/ biotaamazonia.v4n3p88-94

Bwanika, G.N., Chapman, L.J., Kizito, Y., \& Balirwa, J. (2006). Cascading effects of introduced Nile perch (Lates niloticus) on the foraging ecology of Nile tilapia (Oreochromis niloticus). Ecology of Freshwater Fish. 15(4), 470-481. https:// doi.org/10.1111/j.1600-0633.2006.00185.x

Canonico, G., Arthington, A., McCrary, J.K., \& Thieme, M.L. (2005). The effects of introduced tilapias on native biodiversity. Aquatic 
Conservation: Marine and Freshwater Ecosystems, 15, 463-483. https://doi.org/10.1002/aqc.699

Carecho, J., Baduy, F., Guerreiro, P.M., Saraiva, J.L., Ribeiro, F., \& Verissimo, A. (2018). Taxonomic re-evaluation of the non-native cichlid in Portugese drainages. FISHMED Fishes in Mediterranean Environments. https://doi.org/10.29094/FiSHMED.2018.001

Cassemiro, F.A.S., Bailly, D., da Graça, W.J., \& Agostinho, A.A. (2018). The invasive potential of Tilapia (Osteichthyes, Cichlidae) in the Americas. Hydrobiologia, 817, 133-154. https://doi.org/10.1007/s10750-017-3471-1

Celik, M., \& Gökce, M.A. (2003). Determination of fatty acid compositions of five different Tilapia species from the Çukurova (Adana/Turkey) Region. Turkish Journal of Veterinary and Animal Sciences, 27, 75-79. (In Turkish).

Chen, M., Liu, S., Yan, F., Zhou, E., Zhong, X., Ding, M., \& Ye, J. (2019). Complement 1q-binding protein from Nile tilapia (Oreochromis niloticus): Molecular characterization, expression pattern upon bacterial infection and its binding properties. Aquaculture. 500, 31-40. https://doi.org/10.1016/i.aquaculture.2018.09.060

Courtenay, W.R., \& Williams, J.D. (1992). Dispersal of exotic species from aquaculture sources, with emphasis on freshwater fishes. In Dispersal of Living Organisms into Aquatic Ecosystems, Rosenfield A, Mann R (eds). University of Maryland Sea Grant Program: College Park, MD; 49-81.

D'Amato, M.E., Esterhuyse, M.M., Van Der Waal, B.C., Brink, D., \& Volckaert, F.A. (2007). Hybridization and phylogeography of the Mozambique tilapia Oreochromis mossambicus in southern Africa evidenced by mitochondrial and microsatellite DNA genotyping. Conservation Genetics, 8, 475-488. https://doi.org/10.1007/s10592-006$\underline{9186-x}$

Demirayak, F. (2002). Biological diversity-nature conservation and sustainable development. TUBITAK VISION 2023, (in Turkish). Retrieved

from https://www.tubitak.gov.tr/tubitak_content_files/vizyon2023/csk/E K-14.pdf

Dey, M., Eknath, A.E., Sifa, L., Hussain, M.G., Thien, T.M., Hao, N.V., ....\& Pongthana, N. (2000). Performance and nature of genetically improved farmed tilapia: a bioeconomic analysis. Aquaculture Economics and Management, 4, 85-108. https:// doi.org/10.1080/13657300009380262

Dikel, S., \& Celik, M. (1998). Body and nutritional composition of Tilapia (Tilapia sp.) from the Southern Seyhan River. Turkish Journal of Veterinary and Animal Sciences, 22, 517-520. (In Turkish).

Dussenne, M., Gennotte, V., Rougeot, C., Mélard, C., \& Cornil, C.A. (2020). Consequences of temperature-induced sex reversal on hormones and brain in Nile tilapia (Oreochromis niloticus). Hormones and Behavior, 121, 104728. https://doi.org/10.1016/i.yhbeh.2020.104728

Emiroğlu, Ö. (2011). Alien fish species in upper Sakarya River and their distribution. African Journal of Biotechnology, 10, 16674-16681. https://doi.org/10.5897/AJB11.2502

Ewel, J.J., O'Dowd, D.J., Bergelson, J., Daehler, C.C., D'Antonio, C.M., Gomez, L.D., ..., \& Vitousek, P.M. (1999). Deliberate introductions of species: Research needs - Benefits can be reaped, but risks are high. Bioscience, 49(8), 619-630. https:// doi.org/10.2307/1313438

FAO. 2018. The State of World Fisheries and Aquaculture 2018 - Meeting the sustainable development goals. Rome. Licence: CC BY-NC-SA 3.0 IGO. Retrieved from http://www.fao.org/3/i9540en/i9540en.pdf

Ferrari, A. do A., \& Hofmann, P.R. (1992). First register of Biomphalaria straminea Dunker, 1848, in Santa Catarina State. Journal of the São Paulo Institute of Tropical Medicine, 34, 33-35. https:// doi.org/10.1590/s0036$\underline{46651992000100006}$

Ford, A.G.P., Bullen, T.R., Pang, L., Genner, M.J., Bills, R., Flouri, T., ......, \& Day, J.J. (2019). Molecular phylogeny of Oreochromis (Cichlidae: Oreochromini) reveals mito-nuclear discordance and multiple colonisation of adverse aquatic environments. Molecular Phylogenetics and Evolution, 136, 215-226. https://doi.org/10.1016/j.ympev.2019.04.008

Froese, R., \& Pauly, D. (2019). Editors FishBase. World Wide Web electronic publication. Retrieved from www.fishbase.org, version (12/2019).

General Directorate of State Hydraulic Works. (2020). The Report in 2018. Retrieved from http://www.dsi.gov.tr/docs/stratejik-plan/dsi-2018faaliyet

Gökce, M.A., Dikel, S., Celik, M., \& Taşbozan, O. (2003). Investigation of body compositions of three Tilapia species (Tilapia rendalli (Boulenger, 1896), Tilapia zilli (Gervais, 1848), Oreochromis aureus (Steindachner, 1864)) rared in cage condition in the Seyhan Dam Lake (Adana) (In Turkish with English summary. Ege Journal of Fisheries and Aquatic Science, 20 (1-2), 9-14.
Gültepe, N., Bilen, S., Yılmaz, S., Güroy, D., \& Aydın, S. (2014). Effects of herbs and spice on health status of tilapia (Oreochromis mossambicus) challenged with Streptococcus iniae. Acta Veterinaria Brunensis, 83, 125131. https://doi.org/10.2754/avb201483020000

Gürlek, M. (2004). Genetic and morphologic identification of tilapia (Tilapia) species found in Çukurova and Hatay Regions and determination of key characters for species identification (Msc Thesis), University of Mustafa Kemal, Hatay, Turkey.

Havel, J.E., Kovalenko, K.E., Thomaz, S.M., Amalfitano, S., \& Kats, L.B. (2015). Aquatic invasive species: challenges for the future. Hydrobiologia, 750, 147-170. https://doi.org/10.1007/s10750-014-2166-0

Hekimoğlu, M., Say ğı, H., Özden, O., Güleç, F., \& Saka, Ş. (2019). Effects of water temperature on sex differentiation and growth parameters of the Mozambique Tilapia (Oreochromis mossambicus). Aquatic Sciences and Engineering, 34, 22-28. https://doi.org/10.26650/ASE2019499991

Huang, Y., Zheng, Q., Niu, J., Tang, J., \& Wang, B. (2018). NK-lysin from Oreochromis niloticus improves antimicrobial defence against bacterial pathogens. Fish $\mathcal{E}$ Shellfish Immunology, 72, 259-265. https://doi.org/10.1016/j.fsi.2017.11.002

Ibrahim, A.T.A. (2020). Toxicological impact of green synthesized silver nanoparticles and protective role of different selenium type on Oreochromis niloticus: hematological and biochemical response. Journal of Trace Elements in Medicine and Biology, 61, 126507. https://doi.org/10.1016/i.jtemb.2020.126507

Innal, D. (2012). Alien fish species in reservoir systems in Turkey: A review. Management of Biological Invasions, 3(2), 115-119. https://doi.org/10.3391/mbi.2012.3.2.06

Innal, D., \& Sungur S. (2019). First record of non-indigenous fish Hemichromis letourneuxi (Cichlidae) from Pınarbaşı Creek (Burdur, Turkey). The Journal of Graduate School of Natural and Applied Sciences of Mehmet Akif Ersoy University, 10(1), 90-94. https://doi.org/10.29048/makufebed.562523

Khan, A.M., Ali, Z., Shelly, S.Y., Ahamd, Z., \& Mirza, M.R. (2011). Aliens; A catastrophe for native fresh water fish diversity in Pakistan. Journal of Animal and Plant Sciences, 21(2 Suppl.), 435-440.

Kottelat, M., \& Freyhof, J. (2007). Handbook of European freshwater fishes. Publications Kottelat, Cornol and Freyhof, Berlin. 646 pp.

Lukas, J.A.Y., Jourdan, J., Kalinkat, G., Emde, S., Miesen, F.W., Jüngling, H., ..., \& Bierbach, D. (2017). On the occurrence of three non-native cichlid species including the first record of a feral population of Pelmatolapia (Tilapia) mariae (Boulenger, 1899) in Europe. Royal Society Open Science, 4(6), 170160. https:// doi.org/10.1098/rsos.170160

Maan, M.E., \& Sefc, K.M. (2013). Colour variation in cichlid fish: Developmental mechanisms, selective pressures and evolutionary consequences. Seminars in Cell and Developmental Biology, 24(6-7), 516528. https://doi.org/10.1016/j.semcdb.2013.05.003

Martin, C.W., Valentine, M.M., \& Valentine, J.F. (2010). Competitive interactions between invasive Nile Tilapia and native fish: The Potential for altered trophic exchange and modification of food webs. PLoS One, 5(12), e14395. https://doi.org/10.1371/journal.pone.0014395

Mert, R., \& Cicek, E. (2010). Range expansion of introduced tilapia species (Oreochromis niloticus, L. 1758, Cichlidae) in Turkey. Journal of Animal Veterinary, 9(12), 1753-1756. https://doi.org/10.3923/javaa.2010.1753.1756

Mohamed, A.M., \& Al-wan, S.M. (2020). Biological aspects of an invasive species of Oreochromis niloticus in the Garmat Ali River, Basrah, Iraq 13, 15-26. IOSR Journal of Agriculture and Veterinary Science, https://doi.org/10.9790/2380-1302011526

Nico, L.G., Beamish, W.H., \& Musikasinthorn, P. (2007). Discovery of the invasive Mayan Cichlid fish Cichlasoma urophthalmus (Günther, 1862) in Thailand, with comments on other introductions and potential impacts. Aquatic Invasions, 2(3), 197-214. https://doi.org/10.3391/ai.2007.2.3.7

Salzburger, W., \& Meyer, A. (2004). The species flocks of East African cichlid fishes: Recent advances in molecular phylogenetics and population genetics. The Science of Nature - Naturwissenschaften, 91(6), 277-290. https://doi.org/10.1007/s00114-004-0528-6

Schofield, P.J., Slone, D.H., Gregoire, D.R., \& Loftus, W.F. (2014). Effects of a non-native cichlid fish (African jewelfish, Hemichromis letourneuxi Sauvage 1880) on a simulated Everglades aquatic community. Hydrobiologia, 722, 171-182. https:// doi.org/10.1007/s10750-013-1697-0

Tarkan, A.S. (2013). Introduction pathways, impacts and protection measures of non-native freshwater fishes in Turkey and the World. Journal of Fisheries \& Aquatic Sciences, 28(1), 63-104.

Tarkan, A.S., Marr, S.M., \& Ekmekçi, F.G. (2015). Non-native and translocated freshwater fish species in Turkey. Fishery Mediterranean Network, 003: 28p. 
Turkish Statistical Institute. (2020). Retrieved from http:/ / www.tuik.gov.tr/PreTablo.do?alt_id=1005

Vasconcelos, F.R., Menezes, R.F., \& Attayde, J.L. (2018). Effects of the Nile tilapia (Oreochromis niloticus L.) on the plankton community of a tropical reservoir during and after an algal bloom. Hydrobiologia, 817, 393-401. https://doi.org/10.1007/s10750-018-3591-2

Walton, W.E., Henke, J.A., \& Why, A.M. (2012). A handbook of global freshwater invasive species, In: Robert A. Francis, editor, Gambusia affinis (Baird \& Girard) and Gambusia holbrooki Girard (mosquitofish), Chapter: 22, New York: Earthscan, 261-272.

Welcomme, R.L. (1988). International introductions of inland aquatic species. FAO Fisheries Technical Paper No. 294, p. 318 Rome, Italy: FAO.

Wu, L., Bian, X., Kong, L., Yin, X., Mu, L., Wu, S., ..., \& Ye, J. (2019). B cell receptor accessory molecule CD79 gets involved in response against Streptococcus agalactiae infection and BCR signaling in Nile tilapia (Oreochromis niloticus). Fish \& Shellfish Immunology, 87, 212-219. https://doi.org/10.1016/j.fsi.2019.01.012

Yılmaz, S., Ergün, S., \& Soytaş, N. (2013). Dietary supplementation of cumin (Cuminum суminum) preventing streptococcal disease during firstfeeding of Mozambique tilapia (Oreochromis mossambicus). Journal of BioScience and Biotechnology, 2(2), 117-124.

Yilmaz, F. (2009). The comparison of heavy metal concentrations $(\mathrm{Cd}, \mathrm{Cu}$, $\mathrm{Mn}, \mathrm{Pb}$, and $\mathrm{Zn}$ ) in tissues of three economically important fish (Anguilla anguilla, Mugil cephalus and Oreochromis niloticus) inhabiting Koycegiz Lake-Mugla (Turkey). Turkish Journal of Science and Technology, 4(1), 7-15.

Yilmaz, S., Ergün, S., Kaya, H., \& Gürkan, M. (2014). Influence of Tribulus terrestris extract on the survival and histopathology of Oreochromis mossambicus (Peters, 1852) fry before and after Streptococcus iniae infection. Journal of Applied Ichthyology, 30(5), 994-1000. https://doi.org/10.1111/jai.12458

Yildirim, M.Z., Karasu Benli, A. C., Selvi, M., Özkul, A., Erkoç, F.,\& Koçak, O. (2006). Acute toxicity, behavioral changes, and histopathological effects of deltamethrin on tissues (gills, liver, brain, spleen, kidney, muscle, skin) of Nile Tilapia (Oreochromis niloticus L.) fingerlings.
Toxicology
21

https://doi.org/10.1002/tox.20225

Yin, X., Mu, L., Bian, X., Wu, L., Li, B., Liu, J., ..., \& Ye, J. (2018). Expression and functional characterization of transferrin in Nile tilapia (Oreochromis niloticus) in response to bacterial infection. Fish $\mathcal{E}$ Shellfish Immunology, 74, 530-539. https://doi.org/10.1016/j.fsi.2018.01.023

Zworykin, D.D. \& Pashkov, A.N. (2010). Eight-striped Cichlasoma - an allochthonous species of Cichlid fish (Teleostei: Cichlidae) from Staraya Kuban Lake. Russian Journal of Biological Invasions, 1, 1-6. https://doi.org/10.1134/S2075111710010017 